\title{
Gender Issues in Freeman's The Revolt of Mother
}

\author{
Gobinda Puri \\ Janata Multiple Campus, Itahari Sunsari
}

\begin{abstract}
This paper analyses the gender role in Mary E. Wilkins Freeman's (1890) one of the most popular short stories, The Revolt of Mother through a Marxist feminist perspective. The story depicts the gender disparity created by the patriarchal American society of the nineteenth century and the revolt of a female character, Sarah as the indication of the women's movement of 1848. The analysis of the story reveals how females are dominated and oppressed by the males in the family and also in society concerning decision-making affairs. Furthermore, it shows that if male domination and suppression continue without understanding females' desires and fulfilling the promises made for them, they can be turned into rebellions and the traditional gender dichotomy can be broken down in a while as the protagonist appears in the story. This article also relates gender discrimination and proposes possible ways to maintain the equality and harmony between males and females concerning Nepali society.
\end{abstract}

Keywords: Marxist feminism, gender dichotomy, gender discrimination, patriarchal society, Revolt.

\section{INTRODUCTION}

Gender dichotomy that prevails everywhere refers to binary oppositeness such as masculinity and femininity. The American society of the $19^{\text {th }}$ century had also cases of gender discrimination and exploitation (Gardner \& Freeman, 1992) The contributions of women to the family and the society were ignored for a long in history. The labour of the women in the household seems still neglected in many parts of the world. The existence of domination and subordination of women to men can be observed elsewhere even today. The women's sacrifice for the rearing and caring children in the family is being underestimated and their desires and respect are ignored. The short story "The Revolt of Mother" by Freeman introduces us a female character, Sarah, who endures the pain and suffering of bearing and rearing children in the farmhouse of New England for the last forty years and turns into the rebelling situation distorting the gender dichotomy of the then patriarchal American society. The story was published first in The Harper's Bazar in its September issues, 1890 (Freeman, 1890). Later, it was also published in a collection as A New England Nun and other stories next year in 1891. Due to the ability of the writer to represent the truths of the lives of women and the increasing popularity of the story it is reported that Theodore Roosevelt, who was the Governor of New York at that time, highly recommended all mothers to read for its good moral lesson. The Revolt of Mother succeeded so well because Freeman narrated the story using symbolism in male character Adoniram's promise of a new house without sacrificing the structural features of a good story. Although some of the early critics and readers commented on it as a comic fantasy the story proves to be relevant in 
many parts of the world including Nepal where gender role is detrimental for familial and social inequalities. At the first glance, the story seems to have magical fantasy because of its magnificent turn of Sarah's revolt, the portrait the writer draws of the village, and Adoniram's unexpected reversal at the end of the story but it reflects the reality of the society in depth. The woman's revolt against the will of her husband and the will of the entire village and region represents the very serious issues of women's identity and the gender relationship in the society.

Many families today undergo conflict and struggles because of gender roles exposed by the patriarchal society (Barrett, 2014). This paper reveals the gender disparity with the analysis of the conservative relationships between males and females in the story from the feminist perspective intending to bridge the gaps created by the patriarchal familial role of man and woman.

\section{LITERATURE REVIEW}

The story has been analyzed by various scholars during the time it was written and even a century later. Dwyer (1993) argues that the protagonist, Sarah Penn, diffused the gender differences that were created by the patriarchal system of language and values with her actions rather than the voices. Dwyer further contends that Freeman's narrator goes beyond the characters and reflects the discourses and values of the society in the story regarding the role of females. Likewise, Gardner and Freeman (1992) comment that the rebellion of the protagonists in the stories of Freeman as small-scale, finely focused is the gesture of reconciliation and the rebellion against the patriarchal structure in feminist literature. However, White (2008) analyzes the story from a religious perspective and reports that Freeman has used the characters in the story from the Bible such as Saraha and Adoniram to reveal the patience, liberation, possibilities, and religious restrictions of New Englanders women. Grimwood (2013) in "The Revolt of "Mother" and "Consumer Culture" also analyzes the story in the connection to the consumer culture of the then time and argues that the author, as well as the protagonist Sarah Penn, is fascinated with the consumer culture, "the experience of reading local-colour fiction consisted of moving temporarily from a relatively cosmopolitan complex internally differentiated reality to a relatively rustic unitary reading local colour fiction (p. 264). Grimwood concludes that the shifting family from house to the barn, the conversation of Sarah about the barn from the beginning, transform of rustic structure to the more civilized space and the processing of rural resources into consumable goods as fiction show the consumptive desire of American society of 1890. Further, Grimwood (2007) critically analyzes the story through the critical discourse analysis method and reports that the whole story is created with the relationship between gender, power, and architecture as the central theme of life and fiction. Grimwood further claims that all members of the Penn family construct the barn without consulting the mother despite her frequent inquiry and the inadequate structure to live in. Grimwood concluded that no member is accused of the rebellion in the family; it was all because of contemporary politics and power architecture. In a comparative study on two stories namely Mary E. Wilkins Freeman's "The Revolt of Mother" (1890) and Nina Sutherland Purdy's "Mothering: The Story of Revolt" 
(1916), Garvey (2009) highlights the major issues of gender, control of economics on the farm of rural village and the role of the family head for keeping all the members united. Garvey suggests that women should be allowed to take financial control to improve the lives of $21^{\text {st }}$ century rural families. Similarly, Yi (2017) from China deconstructing the gender dichotomy critically analyzes the reasons for changes in the relationship and proposes a way to unite two sexes as androgyny using the feminist approach.

The story has been analyzed from multiple perspectives in different times and contexts. However, after reviewing the available literature it is found that no one has analyzed it from the Marxist feminism perspective relating the relevancy of the story to the Nepali context. So, this paper reports the analysis to bridge the gap.

\section{Theoretical Review}

Multiple feminist theories such as gender theory, intersectional theory, Black feminist theory, globalization theory, Marxist feminist theory, queer theory are available in the field of social and behavioral sciences (Allen \& Jaramillo-Sierra, 2015). Moreover, Fox and Murry (2000) state various traditions of feminism: Marxist feminism, radical lesbian feminism, neo-traditional feminism, and Black feminism. The Marxist feminist perspective is based on the principles of Marxism which focuses on how capitalism uses the family to oppress women and the consequences of the family to woman's life (Sheivari, 2014). Marxist feminism mainly examines the class and gender inequalities as oppression of a powerful and independent system. It often argues that class and gender inequalities reinforce each other and create marginal groups which are often oppressed. Marxist feminism explores how gender, sexuality, and the family-household system that operates concerning the contemporary capitalist society (Barrett, 2014). The Marxist feminist study along with the political economy of women's liberation highlights the value of unpaid labour of the women in the family and society that represent the labour force and also orients the coming generation for not having the ownership of the means of production (Seccombe, 1974). Marxist feminists seem to be focused on the liberation of women politically and economically.

On the other hand, the responsibility of the men as the breadwinner to support other family members enhances the inequitable capitalist economic system. According to Tong (1989), Marxist feminism clarifies how the household works of the women shape their consciousness, identity, and status in the family and society. Therefore, Marxist feminists are mainly concerned with the division of labour that females in the domestic sphere of the family and the male in the workplace. A woman's position in the family may also help to explain the problem strengthening the working-class consciousness. Feminist researchers consider gender issues as the fundamental working principles which mediate women's conditions in society. Feminism among many others is a lens that focuses on the particular gender-related issues through which it poses and argues the centrality of gender in shaping our consciousness, skills, and institutions as well as the distribution of power and privilege. It is the perspective through which the woman's place in the family and the society is studied (Callaway, 1981). 
There are some movements of feminism in the literature which are also known as waves of feminism. The first wave of feminism research operated largely within the conventional paradigm (Westkott, 1979) which is a more self-conscious methodology (Lather, 1988). In the second wave, feminist researchers' task has become to generate and refine more interactive, contextualized methods in the search of patterns rather than prediction and control (Reinharz, 1983). As Gimenez (2000) states in her article, four major currents: liberal, radical, socialist, and Marxist feminism were identified during the women's liberation movement. Gimenez further says that Marxist feminism is sought to take the side of Marxist theory to understand the capitalist sources of the oppression of women. This paper attempts to analyze the story The Revolt of Mother through a Marxist feminist theory perspective as stated by Barrett.

\section{RESULTS AND DISCUSSION}

In Freeman's story "The Revolt of Mother", two main characters Sarah and Adoniram Penn (Mother and Father) represent two sexes of nineteenth-century American society. The female character Sarah initiates the bargaining process with the male character, Adoniram for making the new house. In the story, the male character occupies the larger space though he remains linguistically silent all the time whereas the female voice is louder. Still, she is unheard of.

The story revolves around a bold woman who takes a position against an authoritarian husband because most of Freeman's stories are about New Englanders and their local lives which eventually is considered as the colour movement in American literature (Dwyer, 1993). The whole action in the story takes place on a farm in a rural setting of New England in the spring and summer of a year in the nineteenth century.

Sarah is the main character as a patient, hard-working farm wife and mother who always respects and loves her husband and also takes care of two children. The next character is Adoniram Penn, the husband of Sarah who always ignores the needs of his family and devotes himself to his farm. He speaks little and refuses even to discuss the serious subject of the family. When his wife reminds his promise to build a new house and improve their living condition, he doesn't care much. Another character is their daughter Nanny who is getting married soon. They have a son, Sammy. Other characters are Mr. Hersey (the minister), Hiram (Mrs. Penn's brother who lives in Vermont), Rufus (farm helper), Young Hired Hand (farm helper), and George Eastman (Fiancé of Nanny), other labourers and villages.

Generally, the gender relationship between males and females is biologically determined. However, the same biological difference can be seen as the weaknesses of the women that they should be limited to the household service only. As a result, the labour division of outdoor-oriented men and domestic-oriented women came into practice. In the story too, this division can be found. The main characters Adoniram (male) and Sarah (female) have been assigned different gender roles: the father has complete charge of the farm and any other outdoor business, while the mother is confined to household works like cooking, taking care of the families. Such a division of duties and responsibilities can also be found in the next generation. Sammy, their son, often helps his 
father with the tough works such as loading and unloading the wood, working on the farm, and so on. Similarly, as a boy, he has the right to go to school and study. On the other hand, Nanny, his sister, could only stay at home and help her mother in cleaning, washing, and sewing. The father tells the secret of making a new structure on the farm and Sammy keeps that matter secret for three months without telling his mother and sister. Both male characters think that outdoor works are not the business of women. As argued by Barrett (2014), the male characters seem to be guided by capitalist schooling because male characters seem to earn for the family.

American society of the nineteenth century was based on social stratification that could further strengthen the gender attributes based on biological differences. In the patriarchal society, men as the breadwinners of the families are supposed to be stronger, aggressive, competitive, fearless, independent and intelligent whereas women are said to be opposite to the men: weaker, more passive, not ambitious, cooperative, emotional dependent, gentle and so on. For example, at the beginning of the story, the writer presents the female image as:

\section{She was a small woman, short and straight-waisted like a child in her brown} cotton gown. Her forehead was mild and benevolent between the smooth curves of grey hair; there were meek downward lines about her nose and mouth character. (Freeman, 1890, p. 553)

Similarly, the daughter Nanny with "a pretty girl's face, pink and delicate as a flower" (Freeman, 1890, p. 554) supports the female temperaments. Other language chunks also indicate the female such as "sweet, slow voice", "turned quietly", "wiped the plates slowly and dreamily", and "sewed industriously". On the contrary, the writer has used different language for showing manhood, such as "he hurried the horse into the farm wagon, and clattered out of the yard, jouncing as sturdily on his seat as a boy." Masculinity can also be understood by Sammy's reluctance to stay at home and going out to help his father. It shows that gender roles were existent in the past in American society as it was also based on patriarchal social structures where women were not given much freedom to take any decision at family and even in the family. After nearly a hundred and thirty-five years later, gender inequality can be realized in Nepal as well.

The disparity between gender roles may not be the result of only male domination and suppression. It must be the reflection of the society and social division particularly the consequence of capitalist patriarchal society (Sheivari, 2014). As Marxist feminists argue there is the oppression of Adoniram on Saraha in the story "The Revolt of Mother" because the male character, Adoniram does not listen to his wife and continuously confines her in the household works. The oppression of Adoniram can also be realized in his actions and speech because he does not provide any right to decisions to his wife. That might have been the reason for revolting in the last part of the story. She liberates herself by revolting in the family with her husband. She moves to a new barn challenging the patriarchal system. The reason to shift to the new barn was her discomfort because the house was ill-decorated and the pantry was not good for her as named as "box of a house". Freeman said: 
Here is the entire buttery I've got - every place I've got for my dishes to set away from my rituals in, and to keep my milk-pans in. Father, I've been taking care of the milk of six cows in this place, an' now you're goin' to build a new barn, an' keep more cows, an' give me more to do in it. (Freeman, 1890, p. 554)

The pieces of evidence in the story are enough to conclude that the ways of thinking and the control of the property on males were the sources of gender oppression in the family as Barrett (2014) Barrett indicated in Marxist feminism. The thinking can be rooted in the sociocultural pattern of the society they were living in.

The discussion also indicates that if the male domination and suppression continue without understanding the desires of the female and fulfilling the promises, females may turn into rebellions and the patriarchal dichotomy can be broken down in a while (Tong, 1989). As Freeman states out in the story, "However deep a resentment Sarah might be forced to hold against her husband, she would never fail in sedulous attention to his wants" (Freeman, 1890, p. 555). Sarah spent 40 years obeying her husband and accepting his nature. When her husband started building the barn in the same place where he had promised to build a new house even without communicating with family, she took revolutionary decisions all of a sudden. The evidence indicates the counterattack on male domination and suppression.

The story ends with a subversion of gender dichotomy similar to Yi's (2017) earlier study. The writer has successfully given the message to the readers showing the positive reunion of all the members together in the new house although it was the barn. Father finally realizes his all mistakes instead of blaming his wife and also plans for improving the condition of the house. The mother becomes successful to accomplish her desire at least making her own decision. When the father comes back from his business, he finds all members in the new barn which he had made for the cattle. Adoniram cannot resist the decision that was made by his wife in his absence. He accepts that eventually even if he was not happy.

The American society in the late nineteenth century could be found oppressive to women. They were not given the rights to the property in the family and society. Despite the women's movement and the women's rights activists such as Lucretia Mott, Susan B. Anthony and Elizabeth Cady, women were not granted the right to vote in the elections (Westkott, 1979). Women were allowed to work for menial jobs paying less than men. The protagonist of the story, Saraha sums up the measurable condition of women as:

You ain't found out yet we're women-folks, Nanny Penn said she. You ain't seen enough of men-folks yet to. One of these days you'll find it out, an' then you'll know that we know only what men-folks think we do, so far as any use of it goes, an' how we'd reckon men-folks in with Providence, an' not complain of what they do any more than we do of the weather. (Freeman, 1890, p. 553) 
The above statement clearly shows how much pain and oppression American women were born at that time. Whatever gender discrimination was created by the capitalist society, the women finally got victory over the tyranny of male domination as Sarah could be able to revolt and moved to the new barn. The story represents the women's movement that started in 1848 in America where women's voices were made louder throughout the world. The story still seems to be relevant in Nepalese society where women are still discriminated against in the family and society. Moreover, they can learn the lesson from the story.

\section{CONCLUSION}

As depicted in the story The Revolt of Mother, women are dominated by men in various aspects of life like business, economy, and politics, and even in the familial decision-making processes. The traditional gender dichotomy, male domination and oppression are still in existence in many families in the world. These inequalities are the result of the patriarchal capitalist mindset of society. As the mother resists the gender discrimination, domination, and oppression in the story and liberates herself, the women require themselves to rebel for fulfilling their desires and enjoying equal rights with the men. Sarah Fenn is the representative female character to resist such patriarchy and liberate her from familial restrictions. This story also gives lessons to the women for their equal rights and responsibilities to deconstruct the gender dichotomy and maintain a peaceful and just family and society.

\section{REFERENCES}

Allen, K. R., \& Jaramillo-Sierra, A. L. (2015). Feminist theory and research on family relationships: Pluralism and complexity. Sex Roles, 73(3-4), 93-99. https://link.springer.com/article/10.1007/s11199-015-0527-4

Barrett, M. (2014). Women's oppression today: The Marxist/feminist encounter. Verso Trade. https://books.google.com.np/books?id=U7lvDwAAQBAJ\&sitesec=buy\&source=gbs_vp t_read

Callaway, H. (1981). Women's perspectives: Research as re-vision. Convergence, 14(4), 34.

Dwyer, P. M. (1993). Diffusing Boundaries: A Study of Narrative Strategies in Mary Wilkins Freeman's" The Revolt of'Mother'". Legacy, 120-127.

Fox, G. L., \& Murry, V. M. (2000). Gender and families: Feminist perspectives and family research. Journal of Marriage and Family, 62(4), 1160-1172.

Freeman, M. E. W. (1890). The Revolt of Mother. Harper's New Monthly Magazine, 81, 553-561.

Gardner, K., \& Freeman, M. W. (1992). The Subversion of Genre in the Short Stories of Mary Wilkins Freeman. The New England Quarterly, 65(3), 447-468. 
Garvey, E. G. (2009). Less work for" Mother": rural readers, farm papers, and the makeover of" The Revolt of'Mother'". Legacy, 26(1), 119-135.

Gimenez, M. E. (2000). What's material about materialist feminism? A Marxist Feminist critique.

Grimwood, M. (2007). Architecture and Autobiography in" The Revolt of'Mother'". American Literary Realism, 40(1), 66-82.

Grimwood, M. (2013). “The Revolt of 'Mother”” and Consumer Culture. American Literary Realism, 45(3), 248-267.

Lather, P. (1988). Feminist perspectives on empowering research methodologies. Women's studies international forum.

Reinharz, S. (1983). Experiential analysis: A contribution to feminist research. Theories of women's studies, 162-191.

Seccombe, W. (1974). The housewife and her labour under capitalism.

Sheivari, R. (2014). Marxist Feminism. Encyclopedia of Critical Psychology, 1142-1148.

Tong, R. (1989). Feminist thought: A comprehensive introduction. boulder.

Westkott, M. (1979). Feminist criticism of the social sciences. Harvard Educational Review, $49(4), 422-430$.

White, B. (2008). In the Humble Fashion of a Scripture Woman”: The Bible as Besieging Tool in Freeman's “The Revolt of 'Mother'. Christianity \& Literature, 58(1), 81-92.

Yi, Z. (2017). The Deconstruction of Gender Dichotomy: A Feminist Approach to The Revolt of "Mother". DEStech Transactions on Social Science, Education and Human Science(icesd). 